Lectio Praecursoria

Prologi - puheviestinnän vuosikirja 2018

\section{Sairaalatyöyhteisön hallinnollisessa vuorovaikutuksessa rakennetaan työn resursseja ja työn yhteisyyttä}

Eveliina Pennanen

viestintäkonsultti, FT

eveliina.pennanen@gmail.com

Lectio praecursoria viestinnän väitöskirjaksi tarkoitetun tutkimuksen Hallinnollinen vuorovaikutus sairaalatyöyhteisössä tarkastustilaisuudessa Jyväskylän yliopistossa 6.4.2018. Vastaväittäjänä toimi yliopistonlehtori, dosentti Tuula-Riitta Välikoski (Tampereen yliopisto) ja kustoksena yliopistonlehtori, FT Leena Mikkola (Jyväskylän yliopisto).

Sosiaali- ja terveysalalla kuohuu Suomessa tällä hetkellä enemmän kuin aikoihin. Sote-uudistus ja sen muotoon ja aikatauluun liittyvä epävarmuudet ja epäselvyydet, väestön ikääntymiseen liittyvä palveluiden kysynnän kasvu, naisvaltaisen alan palkkarakenne ja työvoimapula tai työn ja tekijöiden alueellisen kohtaamisen haasteet puhuttavat yhteiskunnassamme. Tuoreimman virallisen tilastotiedon mukaan sosiaali- ja terveysala työllisti Suomessa vuoden 2014 lopussa reilusti yli 385000 henkilöä. Siis noin $17 \%$ työssäkäyvistä ihmisistä. Sairaalat ovat isoja alan työllistäjiä, ja voidaan myös ajatella, että me kaikki kytkeydymme jollakin tavalla sairaaloiden toimintaan: olemme pal- työn tekijään, omaisten tukijaan sekä lakipykälien ja poliittisen päätöksenteon tuntijaan.

\section{Tavoitteet ja toteutus}

Kun työssä voidaan kirjaimellisesti olla elämän ja kuoleman kysymysten äärellä, ei ole yhdentekevää, miten sairaalatyöyhteisöt toimivat. Väitöskirjatutkimukseni lähtökohtana oli halu tuottaa ymmärrystä ja tietoa, jota voidaan hyödyntää sairaalatyöyhteisöjen toiminnan tukemiseen ja kehittämiseen. Siksi halusin alka tutkia tässä viestinnän alan väitöskirjassan sairaalan työyhteisöviestintää ja tarkemmin rajattuna hallinnollista vuorovaikutusta. Väitöstutkimukseni tavoitteena on ymmärtää hallin nollista vuorovaikutusta ja sen ominaispiirteitä sairaalatyöyhteisössä.

Aikaisempi terveysalan organisaatioiden ryh mien vuorovaikutuksen tutkimus on keskittynyt lähinnä hoitotyötä tekeviin ryhmiin ja tiimeihin. Vuorovaikutuksella on todettu yhteyksiä niin tiimin tehokkuuteen, työtekijöiden motivaatioon kuin potilasturvallisuuteen. Sairaalassa, kuten muissakin organisaatioissa tehdään myös hallinnollista työtä. Sitäkin teh dään usein erilaisissa ryhmätilanteissa, kuten johtoryhmissä, henkilöstöpalavereissa tai kehittämis- ja projektiryhmissä. Nämä hallinnolliset ryhmät tuottavat organisaatioille erilaisia resursseja. Kun ne ideoivat, kehittävät, käsittelevät ongelmia, suunnittelevat ja koordinoivat, ne huolehtivat työyhteisön tai organisaation re surssien turvaamisesta ja ylläpitämisestä. Siks niillä on laaja merkitys työyhteisön ja organisaation toimintaan.

Sairaalan työntekijät voivat olla samanaikaisesti jäseninä useissa tavoitteiltaan tai tehtäviltään erilaisissa ryhmissä; he voivat vaikkapa työskennellä niin moniammatillisissa hoitotiimeissä kuin työtä koordinoivissa henkilöstöpala- vereissa. Erilaisten tehtävien ja roolien sekä niihin liittyvien odotusten ja vaatimusten välillä tasapainoilu työtilanteesta toiseen siirryttäessä voi myös kuormittaa työntekijää.

Väitöskirjani pyrkii vastaamaan tutkimuskysymykseen: Mitä on vuorovaikutus sairaalan hallinnollisissa ryhmätilanteissa ja millaisia ovat hallinnollisen vuorovaikutuksen ominaispiirteet sairaalatyöyhteisössä? Toteutin työni artikkeliväitöskirjana. Väitöskirjani koostuu siis neljästä osatutkimuksesta, joiden tulokset raportoin tieteellisissä artikkeleissa, sekä kokoavasta ja arvioivasta osiosta, jossa nivon yhteen tutkimukseni taustan, toteutuksen, tulokset ja johtopäätökset sekä arvioin niitä ja koko tutkimusprosessia. Koko väitöskirjani tutkimuskysymykseen pyrin vastaamaan näiden neljän osatutkimuksen kautta. Kukin niistä tarkastelee aihetta omasta rajatusta näkökulmastaan.

Tutkimukseni menetelmät ovat laadullisia. Laadullisella tutkimuksella on tulkinnallinen ja naturalistinen lähestymistapa maailmaan. Tutkimuskohteita tarkastellaan niiden omissa luonnollisissa viitekehyksissään. Pyrkimyksenä ei ole yleistää, eikä löytää yhtä ainoaa oikeaa tulkintaa tai totuutta, vaan tehdä sosiaalista maailmaa näkyväksi tietystä, valitusta näkökulmasta.

Väitöskirjani tutkimusasetelma oli kehkeytyvä. Tutkimusaihe ja sen rajaus rakentuivat tutkimukseni edetessä aineistolähtöisesti ja osatutkimusteni tulosten ja johtopäätösten perusteella. Tutkimuksen empiirinen aineisto koostui Keski-Suomen sairaanhoitopiiristä kerätystä hallinnollisten ryhmätilanteiden havainnoinneista ja hoitohenkilöstön jäsenten haastatteluista. Havainnointiaineisto koostui viidestä vastuualueen johtoryhmäkokouksesta, kahdeksasta osastopalaverista ja kahdesta yt-kokouksesta. Haastatteluaineistossa oli yhdeksän hoi- 
tohenkilöstön jäsenen haastattelua. Aineisto kerätiin osana Sairaalatyöyhteisön työhyvinvointia edistävät vuorovaikutuskäytänteet -tutkimushanketta.

\section{Väitöskirjan osatutkimukset}

Aloitin väitöskirjatyöni tekemällä kirjallisuuskatsauksen. Kirjallisuuskatsauksessa pyrin ymmärtämään tutkimuskenttää, jolle oma empiiristä tutkimustani asemoin. Selvitin vuosina 2000-2012 julkaistuja tutkimusartikkeleita analysoimalla, miten hallinnollisen ryhmän käsitettä on aiemmissa empiirisissä tutkimuksissa määritelty, millaisia vuorovaikutuksen ilmiöit on tutkittu ja millaisia tutkimusmenetelmiä käytetty.

Tämän osatutkimuksen tulokset osoittivat, ett aiemmissa tutkimuksissa hallinnollinen ryhm määriteltiin ryhmän tehtävän, tavoitteiden ja ryhmän kokoonpanon näkökulmasta. Perinteisiä ryhmäviestinnän teoreettisia lähestymistapoja ei juurikaan käytetty, ja usein ryhmämääritelmät olivat pikemminkin luonnehdintoja tietyssä kontekstissa toimivista ryhmistä tai niiden tavoitteista ja tehtävistä. Hallinnollisten ryhmien moninaisuus tuli kyllä ilmi, mutta johtoryhmien tutkimus hallitsi tutkimuskenttä

Väitöskirjani toisessa osatutkimuksessa tutkin hoitohenkilöstön käsityksiä työyhteisön vuorovaikutuksen merkityksistä työhyvinvoinnin kokemuksen rakentumiselle. Lähestyi työhyvinvointia ilmiönä, jota rakentuu ja jota ylläpidetään työyhteisön jäsenten vuorovaikutuksessa - siis heidän keskinäisessä kanssakäymisessään. Analyysissa hyödynsin fenomenografisen tutkimuksen näkökulmaa käsityksestä, jolla tarkoitetaan mielipidettä syvempi- ja laajempimerkityksisempiä merkityksenantoprosesseja.
Tämän osatutkimuksen tulokset jakautuivat kuulumisen, yhteistyön, vaikuttamisen, tuen ja tiedonhallinnan kategorioihin. Ominaista oli, että nämä prosessit näyttäytyivät jatkumoina, joiden eri kohtiin hyvinvoinnin ja pahoinvoinnin käsitykset voivat asettua. Esimerkiksi vaikuttamisen jatkumolla vapaus valita nousi keskeiseksi elementiksi. Toiset näkivät, että työhyvinvointia rakentuu, kun omaan työhön voi vaikuttaa. Toiset puolestaan kokivat tärkeäksi sen, että heidän ei tarvitse vaikuttaa työhön vaan he voivat keskittyä vain sen tekemiseen ja joku muu päättää ja kantaa vastuun heidän puolestansa.

Tiedonhallinnan käsityksissä näkyi nykyajan työelämälle yleisemminkin melko tyypillinen piirre: yhtenä jatkumon ulottuvuutena oli työntekijöiden tarve saada tietoa ja toisena suuren tietomäärän hallinnan haastavuus, kun tietoa tulee paljon ja resursseja tiedonkäsittelyyn, -arviointiin tai -jalostamiseen ei työssä välttämättä ole. Tämän osatutkimuksen mukaan vuorovaikutusprosesseja on vaikeaa - ja tarpeetontakin - määritellä työhyvinvoinnin teemoissa mustavalkoisesti vain joko myönteisiksi tai kielteisiksi. Olennaisempaa on nähdä ilmiöiden moniulotteisuus.

Keskeisinä ja merkityksellisinä ilmiöinä hoitohenkilöstön työhyvinvoinnille näyttäytyivät tiedonhallinta ja työnkoordinointi, joita toteutetoan sairaalassa esimerkiksi osastopalavereissa. Siksi päätin rajata väitöskirjani kolmannen osatutkimuksen käsittelemään työnkoordinointia hallinnollisessa vuorovaikutuksessa. Käytin aineistona osastopalavereista havainnoimaani aineistoa. Analysoin aineiston induktiivisella laadullisella analyysilla. Tavoitteena oli selvittää, mitä ovat vuorovaikutuksen ominaispiirteet työnkoordinoinnin prosesseissa. Työnkoordinoinnilla tarkoitan tässä työn suunnittelua ja organisointia sekä näistä aiheista keskustelua ja neuvottelua osastopalavereissa.

Tämä osatutkimus osoitti, että työnkoordinointi koostuu työhön liittyvän tiedon merkityksen tämisestä, toiminnan merkityksentämisestä tunteiden hallinnasta ja positioiden hallinnasta. Näissä prosesseissa rakennettiin ymmär rystä sekä työtehtäviin liittyvistä merkityksist että hyväksytyistä tavoista käyttäytyä ja tuntea työyhteisössä. Työnkoordinointi on siis paljon muutakin kuin työtehtävien järjestelyä tai työnjaosta sopimista; vuorovaikutuksessa rakennetaan työyhteisön todellisuutta, kun määritellään hyväksyttyjä tapoja olla, toimia, tuntea ja ymmärtää työssã.

Neljännen osatutkimukseni aiheeseen päädyi pohtimalla ja jäsentämällä aiempien osatutkimusteni tuloksia ja johtopäätöksiä. Vastuu näyttäytyi kiinnostavana ilmiönä, joka oli tut kimusprosessini aikana noussut esiin useass yhteydessä. Sairaalassa vastuun kysymykset korostuvat yleisesti lääketieteellisen vastuun ja potilasturvallisuuden teemoissa, mutta vuorovaikutuksen näkökulmasta vastuuta ei juuri ole tutkittu. Väitöskirjani neljännessä, viimeisessä, osatutkimuksessa tavoitteenani oli kuvat ja ymmärtää vastuun rakentumista sairaala hallinnollisten ryhmien vuorovaikutuksessa. Näkökulmana oli siis vastuun neuvottelemine työyhteisön sisällä. Tutkin, miten vastuuta rakennetaan ja mitä vastuun tyyppejä hallinnollisten ryhmien vuorovaikutuksessa ilmenee.

Analyysissa tarkastelin sairaalan vastuualueen johtoryhmäkokousten ja yt-kokousten viestien sisältöä - siis mitä sanottiin - ja vuorovaikutuksen dynamiikkaa - eli mitä vuorovaikutuksess tapahtui. Lisäksi pyrin laadullisen sisällönanalyysin keinoin tunnistamaan vastuun tyyppejä, joita aihetta tutkineen Hans Lenkin mukaan vat toimintavastuu, rooli- ja tehtävävastuu ja universaali moraalinen vastuu.

Osatutkimuksen tulokset osoittivat, että vastuu hallinnollisessa vuorovaikutuksessa rakentuu yhteisen vastuun luomisen, yksilöllisen vastuun ottamisen ja vastuuntorjumisen prosesseissa. Vastuu oli tyypiltään toimintavastuuta ja rooli- ja tehtävävastuuta. Yhteisöllisen vastuun rakentuminen korostui. Erityisen kiinnostaviksi ilmiöiksi nostan esiin vastuun siirtämisen ja hajauttamisen, joita ilmeni, kun esimerkiksi lääkäri tarjosi hoitajalle vastuuta hoitajan työhön liittyvästä päätöksenteosta, mutta hoitaja siirsi vastuun jollekin toiselle perustellen, että ei tiennyt asiasta tarpeeksi.

\section{Tulokset ja johtopäätökset}

Näiden väitöskirjaani sisältyvien osatutkimusten tulosten pohjalta kokoan, että sairaalatyöyhteisön hallinnollinen vuorovaikutus koostuu prosesseista, joissa rakennetaan ja ylläpidetään 1) työn resursseja ja 2) yhteisyyttä työssä.

Väitän, että vuorovaikutus sairaalan hallinnollisissa ryhmätilanteissa on tiedon-, toiminnan-, työyhteisön- ja vastuunhallintaa. Nämä vuorovaikutusprosessit limittyvät osittain keskenään, mikä näyttäytyy tulosteni perusteella yhdeksi hallinnollisen vuorovaikutuksen ominaispiirteeksi sairaalatyöyhteisössä. Esimerkiksi tiedonhallinta ei rakenna yksin työn suorittamisen ja tavoitteiden resursseja, vaan muotoilee myös työyhteisöä, kun tietoon tai sen kertojaan suhtautumisella neuvotellaan työyhteisön jäsenten positioista ja työyhteisön rajoista. Näin ihmisten välisessä vuorovaikutuksessa rakennetaan tiedon lisäksi työyhteisöä ja sen arvoja.

Sairaalatyöyhteisön hallinnollisen vuorovaikutuksen ominaispiirteeksi muodostuu tulosteni perusteella vastuunhallinta. Vastuunhallintaa 
tehtiin neuvottelemalla siitä, kuka ottaa vastuuta mistäkin tehtävästä, ja määrittelemällä vuorovaikutuksessa, kenellä on oikeus tai velvollisuus ottaa vastuuta tai kieltäytyä vastuusta. Valinnan mahdollisuus vaikuttamiseen tai vaikuttamatta olemiseen näyttäytyi myös merkityksellisenä vastuun ulottuvuutena.

Väitöskirjatutkimukseni tulosten valossa on kiinnostavaa tarkastella sairaalan hallinnollisen työn ja hoitotyön välistä suhdetta. Niitä ei ole tarpeellista, eikä mahdollistakaan, erottaa toisistaan täysin erillisiksi kokonaisuuksikseen, vaan oleellisempaa olisi saada työyhteisö ymmärtämään näiden erilaisten työn muotojen toisiinsa kytkeytyvä suhde. Hallinnollinen vuorovaikutus on mahdollistaja, joka luo resursseja hoitotyön onnistumiselle ja työyhteisön toi minnalle. Sairaalatyöyhteisössä on huomattava, että hoitotyössä toimiviksi ja hyviksi koetut vuorovaikutuskäytänteet eivät välttämättä toimi yhtä tarkoituksenmukaisesti hallinnollisess työssä, jossa tehtävät, tavoitteet ja osallistujiin kohdistuvat odotukset ovat erilaisia. Potilasta elvytettäessä ei ole tarpeen tai mahdollistakaan neuvotella, kuka tänään on vastuussa mistäki toimesta, vaan vastuunjaon on oltava kaikille itsestäänselvää. Hallinnollisen työn tehtävät ja tavoitteet ovat erilaisia, joten myös niiden suorittamista tukeviin erilaisiin viestintäkäytäntei siin on syytä kiinnittää huomiota.

Tutkimukseni tuloksia voidaan hyödyntää työyhteisössä neuvoteltavaan vastuuseen liittyvien kysymysten ratkomisessa. Jos työssä esimerkiksi halutaan jakaa vastuuta laajemmin työntekijöille, ei pelkkä päätös alkaa tarjota vastuuta vielä riitä. Jos hoitaja ei ole tottunut tekemään päätöksiä tai lääkäri jakamaan vastuuta, tarvitaan erilaisten ryhmätilanteiden erilaisten tavoitteiden pohtimista ja sanoittamista, jotta voidaan luoda yhteistä ymmärrystä siitä, mil lainen vuorovaikutus on tarkoituksenmukaista missäkin työtilanteessa.

Samaa johtopäätöstä voidaan peilata myös muihin organisaatioihin esimerkiksi johtamisen näkökulmasta. Jos työyhteisössä johtaja on tottunut tekemään päätöksiä yksin, mutta vastuuta halutaan jakaa laajemmin, tarvitaan työpaikan vuorovaikutuksen aktiivista kehittämistä ja uusien toimintatapojen ottamista osaksi arkipäivän työtä - jos toimintaa halutaan muuttaa kestävällä tavalla. Johtamisen näkökulmasta työyhteisöissä olisi tärkeää siirtyä olettamisen kulttuurista kysymisen ja yhdessä pohtimisen kulttuuriin.

Tutkimukseni tuloksia voidaan soveltaa myös yhteistyön kehittämiseen työelämässä. Monimutkaisia, jatkuvasti muuttuvia ongelmia ei pystytä ratkomaan useinkaan yksin tai vain oman ammattikunnan edustajien kesken. Työelämän tutkimuksen kentällä pohditaan tällä hetkellä esimerkiksi sitä, että ongelmien ratkaisemisen sijaan nykytyössä yhä oleellisempaa on ongelmien hallitseminen, niiden kanssa selviytyminen tai niiden muuttuvuuteen suhtautumisen rakentaminen. Hallinnollisissa ryhmätilanteissa ongelmien käsittelyä ja niihin suhtautumisen rakentamista on mahdollista tehdä työyhteisössä yhdessä. Ryhmätilanteiden voima kannattaakin valjastaa käyttöön ja nähdä kokoukset ja palaverit yhteisen keskustelun mahdollistajina pelkkien tiedotustilaisuuksien sijaan.

Väitöskirjani tulosten avulla voidaan tukea myös hallinnollisen työn arvostuksen edistämistä työyhteisöissä. Hallinnollisen työn näkeminen organisaation tavoitteiden saavuttamisen mahdollistajana ja työyhteisön rakentajana - siis perustavanlaatuisena osana kaikkea työtä ja työelämää - voisi lisätä hallinnollisen työn arvostusta. Tavoitteena voisi olla, että hallin- nollinen työ ei yhdistyisi ajatuksissamme oman päätyön ohessa tapahtuvaksi paperinpyöritykseksi ja kokouksissa kellonvilkuiluksi, vaan kestävän työelämän perustan rakentamisen kannalta elintärkeäksi työksi. Siksi hallinnollisen vuorovaikutuksen kehittämiseen kannatta ehdottomasti panostaa niin sairaaloissa kuin muissakin organisaatioissa. http://urn.fi/URN:ISBN:978-951-39-7376-6 